\title{
Under the Flag of Blue and White: Mary as an A-National Symbol in the Greek-Orthodox Community in Israel
}

\author{
Jonathan Ventura \\ Sociology and Anthropology, Hebrew University of Jerusalem, Jerusalem, Israel. \\ Email: jonathan.ventura@mail.huji.ac.il \\ Received June $5^{\text {th }}$, 2011; revised July 17 th $^{\text {th }}$ 2011; accepted August $19^{\text {th }}, 2011$.
}

\begin{abstract}
Marian devotion and rituals have been the apex of Christian believers' journey for centuries. In spite of its importance in many disciplines, Marian devotion and rituals in Israel have been neglected. In this article I will outline several social and religious aspects of Marian devotion in the Greek-Orthodox community in Israel. Using several case-studies of Marian devotion around the world I will address the question is Mary a national symbol in Israel? Since one of the most important Marian devotion sites is located in Israel and centered in Mary's place of ascension in Gethsemane, addressing this site directly is crucial. I will express a new concept more fitting to the Israeli case-Mary as an a-national symbol. This research is based upon a combination of two main methodologies: participant observations and in-depth interviews with believers (local Greek and Palestinian residents as well as pilgrims) and clergymen. The research focuses on a procession taking place in the Old City of Jerusalem in the end of August, celebrating Mary's legacy and resurrection.
\end{abstract}

Keywords: Mary, Christian Palestinians, Cult of the Virgin, religious processions, Greek-Orthodox

\section{Introduction}

\section{The Feet Walk, the Heart Sings and the Mind Saddens}

On August the $15^{\text {th }}, 1940$, a Greek ship carrying pilgrims on their way to Mary's shrine on the island of Tinos was intercepted by an Italian submarine and drowned. Two months later, Greece entered World War II alongside the Allied Forces and faced Italy's armies and the rest of the Axis' might, declaring the campaign "The Holy War". During maritime battles between Italian and Greek armadas, the later declared their army protected personally by the Virgin from Tinos, taking action against Italy's fascist claims (Seraidari, 2001). As we can clearly see, even in this relatively modern historical incident religious symbols were used to benefit or even forward national-political struggles in order to accentuate the fragile line of justified conflict between the forces of light and darkness.

More than seventy years later, thousands of believers, pilgrims from around the Balkans, Greece and Palestine emerged from the Lions Gate in the Old City of Jerusalem, the rising sun in their eyes, and descended towards the epitaph or their devotion-Mary's tomb at Gethsemane. The ranks of nuns' and priests' black garments mingled with the green and blue of Israeli soldiers' and policemen's uniforms. The Israeli flag's blue and white was left behind temporarily replaced by the GreekOrthodox Church's symbols. Under the archway leading down

\footnotetext{
${ }^{1}$ Taking place on August $25^{\text {th }}$ at 4:00 a.m.

${ }^{2}$ Gethsemane is the burial place of Mary according to early Christian traditions, and is situated outside the Eastern side of the Old City's walls, at the foot of the Mount of Olives.

${ }^{3}$ Taking place on September 5th at 8:00 a.m.

${ }^{4}$ Panhagia in Greek means "the saint above all saints”, a very popular name for Mary in the Greek-Orthodox tradition.

${ }^{5}$ The Mother of Christ.

${ }^{6}$ A Greek-Orthodox church situated across the Holy Sepulchre, whereas lays the icon of Mary. According to informants, this icon was copied from one of the first representations of Mary.
}

to Mary's vacant grave, another flag of blue and white dominated the scene- - the Greek flag.

What is the relationship between Mary's resting place and the state of Israel? What are the believers' feelings towards the geographical context wherein they are marching? And what are the feelings of the Palestinian believers towards said context? In this article I will confront these questions and highlight the differences between other Marian pilgrimage centers and the Israeli context. In this article I will use the qualitative results of a 3 year ethnography (primarily interviews and participant observations) which took part mainly in Jerusalem and Nazareth.

\section{Asceticism and Strife: On the Way to Gethsemane}

The Greek-Orthodox procession taking place at the end of August symbolizes the death of Mary and her resurrection followed by her ascension to heaven led by her beloved Son. This ritual, juxtaposing death and rebirth, dark and light, night and day, is ceremoniously pronounced in the procession's dual or even binary parts. In the first part ${ }^{1}$, worshippers walk along the Via Dolorosa counter its historical route (i.e. from the Holy sepulcher to Gethsemane ${ }^{2}$ ). This first phase of the procession symbolizes the physical death of Mary, hence the early hour following night's end, the mourning songs, and candles, all symbolizing a funeral procession. In the second part ${ }^{3}$, worshippers walk along the Via Dolorosa along its historical route (i.e. from Gethsemane to the Holy Sepulcher). This journey upwards (both metaphorically and physically speaking), towards Jesus' final stance, symbolizes Mary's rebirth, ascension and transformation from a physical, human entity to the Panhagia ${ }^{4}$ -the Holy of Holies, the Theotokos ${ }^{5}$. Along both its parts, the procession is led by the head of the Church of Gethsemane, wearing on his neck the blessed icon of the Matoxion ${ }^{6}$. Apart from marching, singing and praying for loved ones, the worshippers kiss this icon and stop at various "stations" of the Via Dolorosa. 


\section{Multiple Aspects of the Ritual}

The importance of public rituals dominated research in different disciplines for decades. Among these researches pervades Durkheim's, which offered a socio-functional explanation discerning the importance of religious rituals not only as a social process by as a unique process worthy of attention. In his opinion, the purpose of public rituals is to reinforce social solidarity and to maintain the community's continued collective memory (Durkheim, 1965). According to Durkheim, the religious ritual is a social frame wherein group members can meet and interact while validating the group's boundaries. In contrast to Durkheim's functional viewpoint, one can find different theories focused upon the strife and conflicts embedded in religious rituals (Bowman, 1991, 1993, 2001, 2003; Bilu, 2005; Ortner, 1979; Gluckman, 1962; Weingrod, 1990; Eade \& Salnow, 1991).

As the modern harbinger of the interpretive approach to rituals (and Max Weber's “heir” in this context), Geertz (1976: pp. 221-230) emphasizes the cognitive and experiential elements in which individuals can experience only through dramatic occurrences such as rituals. In his opinion, the researcher should focus upon interpreting the ritual according to the narratives shared by its participants, hence highlighting said individuals' experiences. Turner interpreted rituals in a more harmonious way and focused upon the emotional-mystic experience of the believer. Turner (1995) presents Van Gennep's (1960) approach to rituals claiming that during the religious ritual a process of liminality occurs in which the believer stands on the threshold between two worlds, the secular and the sacred. Furthermore, during the sacred journey the pilgrim creates a bond, both mentally and emotionally with other pilgrims, some of whom he would never do so during his "secular" daily life. Other researchers, such as Goffman, $(1963,1967)$ focused less on the ritual's symbolic-theological aspects and more on understanding the meaning given to public rituals by the individuals in said society. The interpretation of the ritual, according to this approach, highlights not the experiential aspects of the ritual, but rather an interpretive aspect focusing on the relationship between the individual and the society in which he lives, such as manifest through religious or secular rituals.

Critiques of these classical approaches to rituals highlighted the lack of attention to inter-group conflicts and lack of communitas (Juschka, 2003; Sklar, 2005). Handelman in his continuous research focusing on rituals suggested a complex and different approach. In his opinion, the public ritual can be seen as a maze in which one might find several entrance doors, where each door symbolizes a different aspect of the ritual. The researcher can crack the lock on each door and reach a dead-end, a solution or keep roaming the corridors looking for different answers (Handelman, 1990). Using this metaphor, Handelman tries to demonstrate the symbolic, cognitive and interpretive complexities the public ritual offers. In deciphering the ritual standing at the center of this article I will highlight the central and unique attributes of the Israeli procession in comparison to other rituals around the world. It is my assertion that rather than being a national symbol, Mary in the Israeli context is a social and ethnic symbol, which although being a key symbol (Ortner, 1979), is not a unifying symbol but a differen-

\footnotetext{
${ }^{7}$ Usually a sacred mountain or hill.

${ }^{8}$ The central goal of the pilgrim during his/hers arduous journey.

${ }^{9}$ Hence, according to Turner the importance of the ritual's temporality, since eradicating social boundaries might endanger cultural norms.
}

tiating symbol, dividing the different ethno-cultural groups taking part in this ritual. In an effort to bypass the multitude of contradictions and complexities comprising this ritual I would like to present two new concepts: a-national symbol and antinational symbol. Following this chapter I will further illustrate and elaborate on these theoretical concepts.

\section{The Many Facets of the Ritual}

In examining the Jerusalem procession, one might conclude that perceiving the public ritual as a mystic process unifying individuals and groups in a common goal is the main attribute in this case. In this ritual indeed we find cultural-mystic-religious elements unifying individuals of the same social characteristics. Furthermore, we will also find many characteristics associated mainly with the individual experiences of the believers taking part in this procession. But, alongside these elements we see a myriad array of conflicts and rivalries (Weingrod, 1990) which characterize the public dimensions of this ritual. These conflicts and strife engulf Arabs and Jews; Jews and Christians; Catholics and Greek-Orthodox; Greeks and Palestinians; pilgrims and locals; Israeli nationality citizens and foreign nationality citizens (mainly Greeks, Russians and the Balkans). Alongside these conflicts runs an ancient struggle involving the Greek community in Jerusalem and the Greek-Orthodox Palestinians, followed by another struggle inside the Greek-Orthodox Patriarchy between the higher clergy occupied mainly by Greeks and the lower clergy occupied mainly by Palestinians (Ventura, 2011). Following Handelman (1990) I will focus in this paper on the complexity of this ritual as well as its uniqueness in standing as an isolated a-national enclave. This uniqueness is characterized by the headline of this article, a ritual which is neither Greek nor Israeli but shares elements of both.

\section{The Textual Ritual}

Eliade (1991) portrayed the religious site as a geographically $^{7}$ and ideologically ${ }^{8}$ prominent place. This holy site functions as an axis mundi, as a metaphysical pipeline linking the heavenly realm and the hellish domains, and in between-our earthly domain. According to his theory, upon arriving at the holy site, the pilgrim is able to "tap" into and "connect" with the saint guarding the site, hence the religious importance of the holy journey. "The sacred” is a key concept in Eliade's theory not only in regard to residing saints, but also in regard to the polarization of the holy site. Accordingly, the holy site represents the existing order between the sacred and the holy, the pure and the tainted, and in between stands the sacred site. Several elements of Turner's (1992) theory regarding the sacred journey might illuminate Eliade's views. Turner (1992, 1995) views the main religious-mystical experience as expanding and unfolding along the way of the pilgrim, which develops and maintains social ties in order to successfully negotiate the road's many hardships. Another central issue in Turner's theory is, in contrast to Eliade which emphasized the geographical centrality of pilgrimage sites, the peripheral locations of said sites. This peripheral location further enhances the religious asceticism due to the added hardships, and excitement upon arriving at the destination. These added hardships contribute not only for the pilgrim's religious experience, but also temporarily erases social boundaries, creating a social environment of parity $^{9}$. In this context I would like to elaborate on the importance of text-oriented geographical sites, meaning, pilgrim sites 
mentioned in the Holy Scripture.

The main Marian textual ritual in Israel is manifested in the Greek pilgrims' will to visit only central sites associated with the life of Jesus and depicted in the gospels. These pilgrims are not tempted to visit neither other marginal sacred sites nor secular attractions such as Masada ${ }^{10}$ or Eilat ${ }^{11}$. Andonis ${ }^{12}$, one of the Jerusalem Greek Community leaders described the preparations made by the Greek pilgrims prior to their arrival:

Jonathan: And the pilgrims arriving here go and visit other places in Israel?

Andonis: They are interested only in the sacred sites, and I try to explain to their Greek guides that there is a huge amount of culture here, go and see Beth-Shean, Caesarea, the Banyas... and they say we have these things in Greece as well, we came to see the sacred sites, it doesn't interest them.

Jonathan: And what does interest them?

Andonis: Religion. It is not all the Greeks, but mostly those who come are simple folk, peasants who save their pennies from the day they were born till one day they will be able to fulfill their dream and come to see the holy land. When they come here they do nothing else, they and their guides (Greek priests) come to Jerusalem and they explore the city and its surrounding 26 Greek monasteries and you know that all around here [Jerusalem] there are sacred places, Bethlehem, Beth-Sahour, a portion of them go to the Judean desert to see the Desert Monasteries, then Jericho and all the other Byzantine monasteries. These monasteries are also equipped with in-house dormitories where pilgrims may sleep such as Gerasimus, Dir Hogla and then Mt. Tabor and Capernaum and Kafr Kanna. Then they pass this whole route from Jerusalem to the north of Israel, reach Capernaum and that's the Northernmost site they reach, although I told them to reach further, to the origins of the Jordan River, but no, they go back to Jerusalem through Nazareth and that's it. That's their route.

Jonathan: Do they stay a few days in Nazareth?

Andonis: No. They stay at Tiberius or Mt. Tabor and then continue on their route so-

Jonathan: So they just walk off the bus in Nazareth, see the Church of the Gospel and drive off?

Andonis: Yes.

As we can see in this description, the Greek pilgrims visiting Israel focus on well-known sacred sites which are mentioned in the Scripture, mainly in the Gospels. These pilgrims visit the Old City of Jerusalem, surrounding monasteries located in the Judean Desert, Mt. Tabor, Kafr Kanna and Capernaum, all of which are mentioned in the Gospels. Surprisingly, although its significant textual importance these pilgrims stop for a brief time at Nazareth ${ }^{13}$ and continue their journey. The pilgrims ignore the much more "touristic" sites and focus upon sites mentioned in the Gospels. The connection to geographical sites through religious texts is very important in this case since most of these pilgrims haven't seen these holy sites, but know them well nonetheless through the Gospels (in addition to oral traditions and Hagiography, which one can find in the Greek Orthodox Church in abundance). Finally, the pilgrims have a con-

\footnotetext{
${ }^{10}$ Masada is a famous mountain facing the Dead Sea where a final stand of the Jewish rebels was made against the Roman army, ending with a mass suicide committed by the Jewish rebels.

${ }^{11}$ Eilat is a very popular vacation site at the southern part of Israel on the shore of the Red Sea.

${ }^{12}$ Following the anthropological ethical code, all the names in this research have been changed.

${ }^{13}$ Mainly, the pilgrims visit the Greek Orthodox Church of St. Gabriel, where the angel announced Mary of her upcoming miraculous conception.

${ }^{14}$ Both in Jerusalem and in Nazareth.
}

tinuous local connection to their hometowns and villages through their local Greek priest-guide.

The abovementioned theories, of Turner and Eliade, explain many aspects of religious rituals but only to a certain extent. Although concepts such as "the Holy Center", and "communitas" evolving through the pilgrims, are true in most cases, they do not provide a full explanation. In order to better understand the ritual standing at the focus of this article we should also understand the many processes of conflict and strife created and evolving by the pilgrims and through their socio-cultural actions. But before I delve into this world of conflicts and strife I would like to elaborate on another important issue relevant to this ritual, which is what I would like to call the "bureaucratization of the ritual”. Apart from the individual, mystic and experiential part of religious rituals, in most rituals we find another world of public facets categorized by beaurocratic elements which sometimes obscure the more intimate and mystic elements experienced by the individual.

\section{The Bureaucratization of the Public Ritual}

Public rituals include not only religious attributes manifesting intimate-spontaneous-mystic-experiential feelings in the world of the individual believer, but also symbolic social dimensions. Symbols (religious, secular or national) stimulates in the individual deep personal meanings, whereas the symbol represents a missing yet present, a tangible yet metaphysic element relevant to daily experiences of the individual. From these reasons the public ritual is crucial in the daily lives of believers. The individual taking part in the ritual experiences several dimensions which in part he is not able to see, yet he is conscious of. These dimensions include both religious icons (physical, tangible, present and may be touched and kissed) creating intimate individual experiences, and public dimensions of social conflict or solidarity (less seen but experienced nonetheless). This combination of elements creates the individual religious experience, according to Handelman:

Public events are phenomenally valid forms that mediate persons into collective abstractions, by inducing action, knowledge and experience through these selfsame forms. They are culturally designed forms that select out, concentrate, and interrelate themes of existence-lived and imagined - that are more diffused, dissipated, and obscured in the everyday... Public events are constituted through their intentionality (their design, or "structure" in an old parlance) and through their practice (their enactment or performance) (Handelman, 1990: pp. 12-15).

Handelman means that public rituals are framed and designed by society binding physical and imagined elements. By combining action, information and personal experience with abstract collective memory religious and secular public rituals are created. These rituals become vortexes of ideas, values and practice. Following Handelman we may call the rigidly constructed public ritual "the bureaucratization of the public ritual". This bureaucratization characterizes not only secular-national rituals but religious ones as well. In the Israeli case ${ }^{14}$ the sacred ritualistic elements are well defined, the believers know exactly the procession's route, which psalms to read and with which melodies. Therefore we see two facets of the public ritual; on the one hand, theories focusing on religious geographical locations as textual attributes (Handelman, 1990); and on the other hand, theories focusing on complex and contradicting elements of the ritual. Similarly to Bowman, Handelman recognizes a 
clear and permanent element of the public ritual and that is the beaurocratic element. But Bowman added another crucial element which is the internal as well as the external conflicts (Bowman, 2003) created between social groups taking part in the religious ritual (Bowman, 1993).

We can see that in this ritual two main elements contradict and complement each other. On the one hand, elements of social order, following religious texts and well-defined geography, hence are creating a sacred site defined by geographical and transience boundaries. On the other hand, elements of religious zeal and well-defined emotional asceticism, both institutionalized and spontaneous. Furthermore, in this ritual dimensions of strife and conflict are current. These contradicting yet complementary elements contribute and create "playfulness" conditions transforming Mary to an a-national ${ }^{15}$ symbol, on which I will elaborate in the next chapter.

\section{Mary as a National Symbol: Case Studies}

Along history religious iconic figures served as national symbols in order to further political goals. Such was the case in different Marian sights, in the island Tinos, in Mexico (Guadalupe), Poland (Czestochowa), France (Lourdes), Bosnia (Medjugordje), Portugal (Fatima) and in Egypt (Zeitun), and I will briefly elaborate on these cases in this chapter. But before I continue, I would like to emphasize an important point. While religious visions and apparitions are common in the Catholic world, they are not so in the Greek-Orthodox world. In this world Mary tends to manifest through sacred icons in different parts of the world. Each icon has its miracle stories uniquely exhibiting Mary's potency ${ }^{16}$ (Dubisch, 1995). In this chapter I will illuminate the national attributes of different Marian locations, and later contradict the Israeli example with these cases.

1) The Greek Mary of Tinos: On March 25 1821 the Greeks rebelled against Turkish rulers and declared a war of independence. To the nationalist claims were added religious differences between Christianity (Byzantium and Greece) and Islam (The Ottoman Empire and Turkey). Following the destruction of the church by Saracens during the $13^{\text {th }}$ century, Greek believers claimed a miraculous recovery of the local Marian icon, which was then hidden waiting future conflicts (Seraidari, 2001). On the day the Greek rebellion was declared, on March $25^{\text {th }} 1821^{\prime}$ according to Greek tradition, the local Marian icon miraculously appeared in order to help the Greek forces battle the Ottoman aggression. This incident symbolizes a tendency to adopt popular religious symbols transforming these to the growing national identity, hence boosting morale in the face of the cruel Islamic foreign empire. In this case, Mary, defender of Tinos and Greece itself stands alongside her followers, saving them from Turkish invaders. On August $15^{\text {th17 }} 1940$ a pilgrimage ship was drowned off the shores of

\footnotetext{
${ }^{15} \mathrm{By}$ the term a-national symbol I do not mean dimensions of conflicts in the way of post-Marxist theories but rather the adaptation of a religious symbol by marginalized social groups.

${ }^{16}$ For example, some women, Greek and Palestinians, told me of the healing abilities of the icons of the Matoxion and Gethsemane in Jerusalem.

${ }^{17}$ The date is meaningful since it is the day of Mary's ascension.

${ }^{18}$ And indeed in the Tinos official site (www.tinos.biz) one can find numerous pictures depicting Greek infantrymen and naval officers taking part in the procession on the Island and even bearing the Mary's icon in their arms.

${ }^{19}$ The Black Madonna's location follows Eliade's theory since its name translates as “the Illuminated Mountain” or "Mountain of Light”.

${ }^{20}$ The crutches of the healed are suspended in the grotto till this day.

${ }^{21}$ The church
}

the Island of Tinos by an Italian submarine. During the ensuing naval battles involving Greek and Italian ships the former announced that the Virgin of Tinos defends the Greek navy against Italian Fascism (Seraidari, 2001). And so, in a newspaper appearing on January $1^{\text {st }} 1941$ the headline read "The Panhagia, leader of our army in battle" ("I Panayía, odhiyítria tou stratóu mas is tas Máhas”). Furthermore, a few years ago the Greek government decided to make August $15^{\text {th }}$, Mary's day of ascension, in the Island of Tinos to a national holiday of the "military forces"18 (Dubisch, 1995). In the Greek case Mary is not only the national benefactor and protector facing external enemies, but also internal ones and first and foremost the communists. An interesting point in this regard is that while our story of Greek autonomy and individuation of the Greek Church is mainly masculine, the highest number of believers taking part in Greek Orthodox rituals are women (Ventura, 2011).

2) Mary the Indigenous of Guadalupe: In the case of Guadalupe, Mexico, Mary appeared before an indigenous local named Juan Diego near Mexico City. As a consequence, in the year 1531 nine million indigenous Aztecs converted to Christianity and embraced Catholicism (Horsfall, 2000). The robe on which Mary's imprint manifested became, to our days, one of the most important pilgrimage destinations in the world. In this case, Mary became a religious keysymbol in South America only during the $16^{\text {th }}$ century (Sklar, 2005). Following the conversion of many of the indigenous nations, Mary had become not only a symbol of socio-religious occupation, but a Pan-American symbol enabling social mobility (Fawrot Peterson, 1991). Between the years 1924-1935 anti-clerical revolutionaries in Mexico depicted La Virgen de Guadalupe on their banner as a symbol of the revolution and dying while crying "Vive Nuestra Señora de Guadalupe!”. Not only individuals took Mary as their symbols, but Mary's church in Guadalupe served as a focal point for revolutionaries' demonstrations (Perry \& Echeverria, 1988).

3) The Black Madonna of Czestochowa, Defender of Poland: The Black Madonna at Jasna Gora ${ }^{19}$ in Czestochowa, Poland has been transformed to a national symbol after aiding the Polish Kingdom during the $14^{\text {th }}$ century. According to local traditions, Luke painted Mary while she told him of the happenings of Jesus' life and death, what became the Gospel by Luke. Due to these reasons (healing and guarding abilities) The Black Madonna of Czestochowa has become a national symbol and a Polish Patron defending the country against heathens and enemies. For example, not only did The Black Madonna stood against Swedish conquest attempts during the $17^{\text {th }}$ century, but also stood in favor of Polish independence movement during the 1980es in a struggle against atheist and communist doctrines (Galbraith, 2000).

4) Mary the Healer of Lourdes: During the year 1858 Mary appeared 18 times in the small village of La Salette near Lourdes in France to a local 14 year-old girl named Bernadette Soubirous. In the local Grotto where Mary appeared a stream started to flow, stimulating several medical miracles, in which cripples began walking and the sick were healed ${ }^{20}$ According to Keselman (1978), the Church used different visions and apparitions during history as a tool of empowerment against claims of rationality and science ${ }^{21}$. The Lourdes' apparitions supplied the French Church ample proof as to the relevance and importance of Mary, in contradiction to scholars' beliefs. As a consequence, these ap- 
paritions drew the attention of Pope Pius $10^{\text {th }}$ (Harris, 1999; Dahlberg, 1991; Eade \& Sallnow, 1991). Every year over 4 million pilgrims visit Lourdes, mainly between Easter and the day of Mary's Ascension in mid-August. "Rome is the head of the church, but Lourdes is its heart", say the pilgrims, meaning that while the "brain" of the Church stands in St. Peter, its heart lies in Lourdes. Believers viewed Bernadette as a living saint present at the site, and even other sick believers as saints sent by Jesus to test their faith (Dahlberg, 1991). In this context we can interpret sick and ailing believers as bridging the gap between our mundane daily world and the heaven above (Eliade, 2005, 1991).

5) The Mother of Peace, Mary of Medjugorje: While Eliade wrote of the sacred site located at a central location, the Bosnian case better resembles Turner \& Turner's interpretation of marginally located sacred sites. The Bosnian site of Medjugorje became a central religious pilgrimage site, sacred to the three monotheistic religions in the area (Catholics, Orthodox and Muslims), only after Mary appeared before several local children which during their religious trance felt no pain and lost grasp of reality (Jurkovich \& Gesler, 1997). In the village of Medjugorje after appearing to several local children in 1981 till now ${ }^{22}$ Mary appears at the local church and delivers messages of worldly peace to her followers (Horsfall, 2000). The Bosnian case is interesting for it resembles some of the attributes of the Israeli ritual: a sacred site standing in the core of a socio-cultural conflict between different groups vying for political leverage. Researchers see the apparitions of Medjugorje as an ample example of using a religious meta-symbol for political goals. Bosnia-Herzegovina, just like other parts of Eastern Europe in the 1980's, was under Communist rule, viewing the Church as an obsolete medieval relics. Mary's apparitions in Medjugorje supplied the Church with the right opportunity to show the local atheist government God's might and relevance (Perry \& Echeverria, 1988). As we shall see in the following lines, similarities between Medjugorje and the Jerusalem ritual are apparent.

a. Both Medjugorje and Gethsemane are located in areas of religious and political conflict. Furthermore, alongside religious strife abundant in this region, till the fall of the Communist state, Bosnia-Herzegovina suffered struggles between atheist governments and religious groups (Jurkovich \& Gesler, 1997). While pessimists viewed these apparitions as a Christian tool for eliminating Muslims, others saw Mary as a harbinger of worldly peace and understanding between opposing socio-cultural groups (Sudetic, 1993). Rivaling groups turned to the Scriptures to add textual meaning to the village of Medjugorje naming it "New Bethlehem" and "The New Holy Land", hence adding to their rightful claims (Jurkovich \& Gesler, 1997).

b. Another resemblance between Medjugorje and Mary's ritual in Jerusalem are the attempts of local governments to turn these sacred sites to tourist attractions. In both cases political conflicts ${ }^{23}$ resulted in a serious

\footnotetext{
${ }^{22}$ Mary's official messages can be found at www.medjugorje.org

${ }^{23}$ Civil wars in Bosnia-Herzegovina and the El-Aqssa Intifada in Israel.

${ }^{24}$ While in the first procession I witnessed the estimate number of pilgrims was approximately 2,000, two years later the number reached 5000 and increasing since.

${ }^{25}$ Lucia dos Santos, 9 years old, and her two cousins_-Francisco and Jacinta Marto

${ }^{26}$ From Mary's first apparition to the rise of power of Salazar.

${ }^{27}$ Pictures of the Zeitun apparition can be found in numerous internet sites.
}

downfall of tourists arriving at both countries. In both cases local governemts tried to portray a daily experience of "business as usual", and indeed in the years I have researched the Israeli rituals I saw a steady increase of pilgrims between the years 2003-2009² . In Bosnia-Herzegovina as well numbers of pilgrims are constantly increasing (Connell, 1992).

c. Finally, another resemblance is a multitude of religious beliefs in a small geographic location. In the Jerusalem procession one finds not only Christians but also Muslims, in the same way as Medjugorje attracts different religious-ethnic groups (Vukonic, 1992), praying to the same merciful Mother (Pervan, 1987). As a result, Mary has become a trans-national and multi-cultural symbol relevant to human beings wherever they come from since she is a cosmic mother and the "Mother of Peace" (Hill, 1987).

6) Mary of the Poor, Fatima: In 1917 the revolutionary regime declared a separation of state and church and the abolishment of monasteries. WWI hardships, hunger and poverty created a reality in which thousands of beggars and poor folk hungered for food and yearned for saintly and heavenly help intervention. At the beginning of May 1917, Mary appeared to 3 Fatima-born children ${ }^{25}$ for 6 months. Mary, introducing herself as the "Angel of Peace" and later that year as the "Angel of Portugal” (Perry \& Echeverria, 1988), foretold the children of a future, greater war which will engulf the world in. Mary also showed the children a glimpse of the true essence of Hell (Zimders-Swartz, 1991). Apart for several secret messages Mary’s messages gained great popularity and spread through the Christian world like wildfire. During the tragic events between the years $1917-1932^{26}$ Portugal witnessed 39 governments, mass demonstrations, bombings, political assassinations, bankruptcy and a brief civil war, which attributed the Cult of the Virgin un unprecedented popularity (Perry \& Echeverria, 1988).

7) Mary under the Crescent Moon, Zeitun: Mary's appearance in the Coptic church of Zeitun (1968), on the outskirts of Cairo, occurred during a period in which Egyptian authorities tried to rebuild their national pride. After the loss of the Six Days War, an occurrence of this magnitude could make thousands of believers flock to the sacred Egyptian site. Although Mary was not an Egyptian national symbol, she served a functional goal of nurturing national pride (Davis \& Boles, 2003). The unique feature of Zeitun is the fact that Mary appeared simultaneously to thousands of believers who even took her picture hovering over the chapel's roof ${ }^{27}$. Perry \& Echeverria (1988) suggested a theoretical model to analyze religious visions. Accordingly, the characteristics of modern apparitions are:

a. Background: Social chaos, political and economic crises, an "ecclesiastic threat" (modern age, science, revolutions, national movements), apparitions occur mostly in under-developed rural areas.

b.The "seer": Un uneducated girl, peasant, poor family, had had former visions or heard of them, has a connection to other Marian cults.

c. The apparition: Usually begins with a lightning followed by the appearance of a luminous Lady, clothed in regal robes, hovering or weeping, describing herself as the "Virgin" of a certain description.

d.The message: Apocalyptic messages were meant strictly for the Pope's ears, usually consisting of a secret part 
meant for the Clergy and a lesser part meant for all Christians. The need for abstinence, piety and prayer is adamant in Mary's message.

e.Miracles: Physical healing, a fountain flowing directly from the apparition site etc.

f. Reactions: Church officials, dreading heresy, try to abolish the seer's claims by threatening their families. Masses gather to the apparition site but are thrown back by police forces. Slowly, due to local and national pressure the Pope relents and declares the apparition site as a sacred site.

The discussed sites are but a mere example, since along history 21,000 apparitions were documented (Horsfall, 2000). In the following chapter we will see that although the Israeli site is one of the most important ones, since it is Mary's ascension site, it does not follow the same pattern as other major sites. In the Israeli site, Mary serves not as a national symbol, but rather as a marginal symbol, indentified with a marginal community in Israeli society, Christian Palestinians in general, and Greek Orthodox in particular.

Israeli reality is saturated with conflicts and ethno-religious-cultural differences culminating in violence ${ }^{28}$. Sered (1991) compared rituals of three monotheistic major female saints ${ }^{29}$ and came to interesting similarities: the ritual form and wishes from the saints; female saints situated in patriarchal worlds. Bowman (1993) ascertains that the Christian-Palestinian populace in Israel is situated between a rock and a hard place. On the one hand, Muslims consider them as non-Arabs, and on the other hand, Jews consider them as Arabs. As a consequence, situated in the margin's margin of Israeli society, many Christian youth leave Israel and immigrate to neighboring Arabs countries, Europe or the United States ${ }^{30}$.

Another important point illuminated by Bowman (1991) claims that we should view Jerusalem "not [as] $a$ holy city but a multitude of holy cities", due to the multitude of religions local to the area. According to Bowman, Jerusalem depicts a varied narrative accentuating a multitude of discourse forms dealing with religion in general, and Jerusalem in particular. I will now turn to further highlight the case of "Israeli Mary".

\section{Under the Flag of Blue and White: Israeli Mary}

In contrast to other Marian centers I've mentioned earlier, whereas Mary serves as a national symbol, the Jerusalem ritual is far from this concept. In Marian rituals around the world the national element is central in its importance. Such is the case in the French Marian center in Lourdes, which stands as a clear French national symbol to all the pilgrims arriving there (and the connection to Marian is not trifle). In the Israeli case, however, Mary not only does not represent the Israeli state but is even viewed as an "anti-national" symbol eliminating the Israeli context from the religious reality of the procession. As we have seen, in all the other cases I have portrayed, Mary is viewed, by locals as well as pilgrims, as a national symbol. In ${ }^{28}$ Such a case happened in a Greek-Orthodox procession taking part on September 5th 2005, when Jewish residents of the Old City of Jerusalem confronted priests leading the procession:

http://www.jpost.com/NASApp/cs/ContentServer?pagename=JPost/JPArtic le/ShowFull\&cid=1125886816885

${ }^{29}$ Mary, Rachel and Fatima.

${ }^{30}$ Christian Palestinians I have interviewed in the Old City of Jerusalem and Nazareth have described the same.

${ }^{31}$ The Palestinians are a marginal group in Israeli society, and Christian Palestinians are a margin of Palestinian society.

${ }^{32}$ As did informants describe both in Jerusalem and Nazareth.
Lourdes Mary is a "French saint”, alongside other major female figures such as Marian and Jeanne d'Arc. In Bosnia, different ethno-religious groups vied to take control over the apparition site and "nationalize" Mary. In the Polish case, Mary has been a priori "canonized" as a Polish patron since the $16^{\text {th }}$ century. In the Mexican case, Mary of Guadalupe has been seen as a panLatino saint as early as the $19^{\text {th }}$ century (Bosca, 2005).

In contrast, Mary in the Jerusalem ritual is a marginalized symbol (Sa'ar, 1998), or even a symbol of the margin's mar$\operatorname{gin}^{31}$. Furthermore, none of the groups participating in the ritual view themselves as Israeli. Pilgrims bear their nationalities (Greek, Russian, Balkan or other), manifested by a European passport, during their visit to Israel (Bowman, 1991), while Greek-Orthodox Palestinians describe themselves in a-national definitions, as we can see in Andonis' description:

Jonathan: So you define yourselves as Greeks living in Israel which is not Greece, but a Greek province?

Andonis: Look, I am an Israeli citizen, but I am Greek, and in my passport is written "Greek nationality", I cannot deny it, I have been living here for 55 years but I was born in Greece.

Greek-Orthodox Palestinians prefer to define themselves as Palestinian, even those living in Israel, not only in the Palestinian Territories ${ }^{32}$. A for the personal identity of the Palestinian believers, the most common description was one of confusion and lack of identity coherence, as described Emile, a Palestinian resident of the Old City of Jerusalem:

Jonathan: So, upon asking, what is yours, Samir's or Aziz' identity, will you describe yourself as Greek, Christian, Arab, Israeli?

Emile: It is a constant dilemma we live with, and a very difficult one. As for myself, personally, since I was a child, they always said we were Arabs, and this new reality in which we live in, the first and second intifadas and all these occurrences, many things shattered along the way, it is like in the last intifada Christian Palestinians were seen as traitors, and why? because they refused to fight the Jews.

Jonathan: Who viewed them as traitors? Muslims?

Emile: And why? Because we do not go and kill [the Jews] because it is forbidden in our faith, it is very simple; we don't have a concept of struggling violently on a piece of land or other issues.

Jonathan: And Jews view you as second-rate citizens?

Emile: True, not only as second-rated citizens but as enemies.

Jonathan: Because you are Arab?

Emile: Exactly.

Jonathan: Meaning, that the Jews view you as Arabs, and the Muslims see you as collaborating with the Israeli government.

Emile: Yes.

As we see in this description, Emile's identity is not Israeli and not Arab, since these definitions stem from religious-based. The problematic situation of Greek-Orthodox Palestinians led me to think of the term a-national symbol in relation to the complex relationship between nationality, religion and Marian processions. In the term a-national symbol I do not mean to imply hegemonic political struggles such as portrayed by post-Marxist theories, but rather a tendency of marginalized ethno-religious groups to adopt a meta-symbol, while staying in society's margins, hence marginalizing the said symbol. Greek-Orthodox Palestinians in Israel do not view Mary as a meta-symbol nor as a national symbol, but rather take part in a process in which Mary is marginalized by the nation state. In that manner one may better understand Emile's description of 
the Marian procession taking part in Jerusalem:

Jonathan: So, when I take part in the procession, whether I am a Greek or Serbian believer, I am still in Israel, right? Do I take part in an Israeli ritual or a global one?

Emile: It is exactly global, Orthodox is Orthodox, and how did they invent this thing called Orthodox? There were different opinions and heated arguments in the Church, whether to go "by the book" or by the Patriarch, and then there was the splitting between the Catholics and the Christians [Orthodox], and the Catholics created the tradition of canonizing a person after his death...

As we see in Emile's description, in the Orthodox world Mary is not related to the national state in the same way as in Catholicism. In this case, Mary is viewed as a global, Pan-Orthodox symbol, which is excluded from the Israeli geographical reality. In that way, pilgrims or Greek-Orthodox Palestinians arriving at Gethsemane at the highlight of the procession see Mary not as a part of the Israeli context, but rather as a global Christian symbol or as a Pan-Greek-Orthodox meta-symbol. The Greek flag furling above Gethsemane's entrance dulls the global context, but accentuates the separation of the sacred site of the Israeli nation state, as we can clearly understand from Emile's and Samir's description:

Jonathan: At the end of August I went to Gethsemane and I saw there a Greek flag.

Emile: Of course you saw a Greek flag. But the Greeks insisted a Greek flag should fly there, since they rule the area.

Jonathan: And what would think a tourist or pilgrim arriving at the site and seeing a Greek flag there?

Emile: If he is Greek-Orthodox he will think the area is Greek, but it is a fact that it is Greek.

Jonathan: and how does that relate with the fact that he is standing on Israeli soil?

Samir: Just as he goes to his local church, they [pilgrims] do not relate to that.

Jonathan: Does the pilgrim think only of Mary?

Samir: Yes. In the church when you attend, you come to a church according to its patron saint and repent from your sins, that's what matters, what might drive him crazy is if the authorities deny access to the church [...]

Jonathan: And when a Greek peasant walks along the procession's route and sees the Greek flag, does he ask himself whether he is still in Israel or rather in a Greek enclave?

Emile: No. I never think of Israel, now when I go to Greece I feel a national pride.

Jonathan: Do you feel you are Greek?

Emile: Let's say that they [Greek authorities] would never make you feel as a Greek, but as a Greek-Orthodox you will always fell Greek inside [...] till today I cannot explain myself why and how I feel Greek inside, but my heart is Greek.

According to this exchange, Gethsemane is viewed as a Greek complex, but an Orthodox believer descending the church's stairs does not view the site as Greek but rather as globally-Orthodox. Furthermore, while Israeli society excludes these believers from the mainstream national identity, they feel pride in their Greek patriotism. In this description Mary as a religious symbol is not viewed as a national symbol but rather as a marginalized icon symbolizing socio-cultural groups excluded by the Israeli government. In this a-national context the Israeli contents is pushed into a corner of the believers' consciousness. In that way, we do not deal with a patriotic pride

\footnotetext{
${ }^{33}$ Such as traditional Greek soirées consisting of traditional dances and food in Jerusalem.
}

but rather an individual separation from the national ethos and the creation of a socio-cultural group standing under a religious, rather than a national, flag.

In both the main groups taking part in this procession the term a-national ritual takes a different form. In the Greek population the term is manifested in the form of exporting Greek ideas, values and norms and the annulment of Israeli values and norms while keeping unique cultural attributes (Bowman, 1991, 1993) $^{33}$. In the Greek-Orthodox Palestinian communities as well, the main socio-cultural norms and values are not Israeli but either Arab-Palestinian or western-European, manifested in seeing higher education in Europe or the United States as a first stage in a successful immigration process, or a growing tendency to immigrate to Western countries such as Europe, Canada or the United States. In this outlook Israel is seen as an "immigration springboard" to more liberal and multicultural countries.

\section{Summary}

Finally, I would like to illustrate the fine line separating the dual meaning of this unique Marian procession. On the one hand, we witness a very emotional, personal and experiential ritual for the individual believer. On the other hand, we witness a very orderly ritual accentuating social norms and values. During this ritual a marginalized group uses the religious platform of the ritual in order to express socio-cultural emotions and even creating an anti-national protest. In this regard we can better understand the term I have suggested in this article, an a-national ritual consistent of anti-national socio-religious elements.

In contrast to other research approaches differentiating the diverse elements of the ritual, emotional and a-personal, spontaneous and planned, public and personal, secular and religious, we need to take all these elements in order to better understand religious rituals in complex societies. The ritual I have portrayed in this article consists of spontaneous elements as well as well-defined and organized ones; this ritual consists of personal-experiential elements alongside public-collective elements. Therefore, in order to better understand it we should combine different theories of solidarity and conflict and to search and interpret other dimensions of religious ritual in general. Only through multi-faceted approaches we would be able to truly comprehend religious rituals in all their complexities.

Finally, the terms a-national ritual and anti-national ritual, will benefit, in my eyes, sociological and anthropological researches not only in the understanding of religious rituals, but of marginalized social groups standing in the midst of an ethno-cultural conflict. Using these terms will enable researchers the flexibility to better understand religious rituals through national concepts in general, and in areas of conflict in particular.

\section{References}

Bilu, Y. (2005). Shushbiney hakdoshim. Haifa: Haifa University Press. Bosca, R. (2005). Evita: A case of political canonization. In J. Hopgood (Ed.), The making of saints: Contesting sacred ground (pp. 59-74). Tuscaloosa: The University of Alabama Press.

Bowman, G. (1991). Christian ideology and the image of a holy land: The place of Jerusalem pilgrimage in the various Christianities. In J. Eade, \& M. Sallnow (Eds.), Contesting the Sacred (pp. 98-121). London: Routledge.

Bowman, G. (1993). Nationalizing the sacred: Shrines and shifting 
identities in the Israeli-occupied territories. Man, 28, 431-460. doi:10.2307/2804234

Bowman, G. (2001). The violence in identity. In B. Schmidt, \& I. Schröder (Eds.), Anthropology of violence and conflict (pp. 25-46). New York: Routledge.

Bowman, G. (2003). Constitutive violence and the nationalist imaginary: Antagonism and defensive solidarity in 'Palestine' and 'Former Yugoslavia'. Social Anthropology, 11, 319-340.

Connell, J. (1992). The visions of the children: The apparition of the blessed mother at Medjugorje. New York: St. Martin’s Press.

Dahlberg, A. (1991). The body as a principle of holism: Three pilgrimages to lourdes. In J. Eade, \& M. Sallnow (Eds.), Contesting the sacred (pp. 30-50). London: Routledge.

Davis, P., \& Boles, J. (2003). Pilgrim apparition work: Symbolization and crowd interaction when the Virgin Mary appeared in Georgia. Journal of Contemporary Ethnography, 32, 371-402. doi:10.1177/0891241603253492

Dubisch, J. (1995). In a different place: Pilgrimage, gender and politics at a Greek Island Shrine. Princeton: Princeton University Press.

Durkheim, É. (1965). The elementary forms of the religious life. New York: Free Press.

Eade, J., \& Sallnow, M. (1991). Introduction. In J. Eade, \& M. Sallnow (Eds.), Contesting the sacred (pp. 1-29). London: Routledge.

Eliade, M. (1991). Images and symbols: Studies in religious symbolism. Princeton: Princeton University Press.

Eliade, M. (2005). The myth of the eternal return. New Jersey: Princeton University Press.

Fawrot Peterson, J. (1991). The virgin of Guadalupe: Symbol of conquest or liberation? Art Journal, 51, 39-47. doi:10.2307/777283

Galbraith, M. (2000). On the road to Czestochowa: Rhetoric and experience on a polish pilgrimage. Anthropological Quarterly, 73, 61-73.

Gluckman, M. (1962). Les rites de passage. In M. Gluckman (Ed.), Essays on the ritual of social relations (pp. 1-52). Manchester: Manchester University Press.

Geertz, C. (1976). From the native's point of view: On the nature of anthropological understanding. In K. Basso, \& H. Selby (Eds.), Meaning in anthropology (pp. 221-237). Albuqeurque: University of New Mexico Press.

Goffman, E. (1963). Behavior in public places. New York: The Free Press.

Goffman, E. (1967). Interaction ritual. New York: Anchor Books.

Handelman, D. (1990). Models and mirrors: Towards an anthropology of public events. Cambridge: Cambridge University Press.

Harris, R. (1999). Lourdes: Body and spirit in the secular age. London and New York: Allen Lane the Penguin Press.

Hill, J. (1987). Medhugorje. Concord: Center for Peace.

Horsfall, S. (2000). The experience of Marian apparitions and the Mary cult. The Social Science Journal, 37, 375-384. doi:10.1016/S0362-3319(00)00075-6

Jurkovich, J., \& Gesler, W. (1997). Medjugorje: Finding peace at the heart of conflict. Geographical Review, 87, 447-467. doi: $10.2307 / 215225$

Juschka, D. (2003). Whose turn is it to cook? Communitas and pilgrimage questioned. Mosaic: A Journal for the Interdisciplinary Study of Literature, 36, 189-204.

Kselman, T. A. (1978). Miracles and prophesies: Popular religion and the church in nineteen-century France, unpublished Ph.D. Thesis, University of Michigan.

Ortner, S. (1979). On key symbols. In W. Armand, \& E. Zartman Vogt (Eds.), Reader in comparative religion (pp. 92-98).. New York: Allyn \& Bacon.

Perry, N., \& Echeverría, L. (1988). Under the heel of Mary. Routledge: London and New York.

Pervan, T. (1987). Our lady is guiding the community. In J. Hill (Ed.), Medjugorje (pp. 19-23). Concord: Center for Peace.

Sa'ar, A. (1998). Carefully on the margins: Christian Palestinians in Haifa between Nation and State. American Ethnologist, 25, 215-239. doi:10.1525/ae.1998.25.2.215

Seraidari, K. (2001). La vierge de tinos: Le couer sacre de l'état grec. Archives de Science Sociales des Religions, 46, 45-59.

Sered, S. (1991). Rachel, Mary and Fatima. Cultural Anthropology, 6, 131-146. doi:10.1525/can.1991.6.2.02a00010

Sklar, D. (2005). The footfall of words: A reverie on walking with Nuestra senora de Guadalupe. Journal of American Folklore, 118, 920. doi:10.1353/jaf.2005.0012

Skrbis, Z. (2005). The apparitions of the virgin Mary of Medjugorje: The convergence of Croatian nationalism and her apparitions. $\mathrm{Na}$ tions and Nationalism, 11, 443-461. doi:10.1111/j.1354-5078.2005.00213.x

Sudetic, C. (1993). A shrine in Bosnia is now illuminated by rockets. New York Times. September 26th.

Turner, V. (1992). Blazing the trail: Way marks in the exploration of symbols. Tucson \& London: The University of Arizona Press.

Turner, V. (1995). The ritual process: Structure and anti-structure. New Jersey: Aldine transaction.

Turner, V., \& Turner, E. (1978). Image of pilgrimage in Christian culture. New York: Columbia University Press.

Van Gennep, A. (1960). The rites of passage. Chicago: University of Chicago Press.

Ventura, J. (2011). Conflict and strife on the way to Gethsemane. Israel affairs. in Press.

Vokunic, B. (1992). Medjugorje's religion and tourism connection. Annals of Tourism Research, 19, 79-91. doi:10.1016/0160-7383(92)90108-2

Weingrod, A. (1990). The saint of beersheba. Albany: SUNY Press.

Wolf, E. (1958). The virgin of Guadalupe: A Mexican national symbol. The Journal of American Folklore, 71, 34-39. doi:10.2307/537957

Zimders-Swartz, S. (1991). Encountering Mary: From la Salette to Medjugorje. Princeton: Princeton University Press. 